\title{
Community Participation Model in Development of Education Facilities and Infrastructure
}

\author{
Musyarapah $^{1}$, Helmiannoor $^{2}$ \\ Department of Tarbiyah, Islamic High School, South Kalimantan, Indonesia ${ }^{1,2}$ \\ \{hjmusyarrafah990@gmail.com $\left.{ }^{1}, \underline{\text { helmiyannor@yahoo.co.id }}{ }^{2}\right\}$
}

\begin{abstract}
The public participation is needed in the development and construction of education, especially in the event of Islamic education facilities and infrastructure. Society is one of the main factors to support education program; the efforts of the government to increase the community participation in implementing of education in schools; public assistance will encourage a sense of community ownership of learning, and it will raise the public awareness to improve the quality of education in schools. This study focuses on how the model of public participation in the development of infrastructure and facilities in MTs NIPI Rakha Amuntai. This study used qualitative research. This study applied case studies method. The technique of data collection used: in depthinterview, participant observation, and documentation study. Data were analyzed in the analysis of individual sites data with data analysis: data reduction, data presentation, and conclusion. Data were validated through credibility, transferability, dependability, and conformability. The research result showed that: the model of public participation in development facility and infrastructure in MTs NIPI Rakha Amuntai with the interest-based is in the $3^{\text {th }}$ level (form: representative, top-down: sustainability, bottom-up: leverage); SMPIT Ukhuwah Banjarmasin with needs based is in the $2^{\text {nd }}$ level (form: instrumental, top-down: efficiency, bottom-up: cost). Based on the substantive finding above, thus finding in this research is participation based needs of the local community.
\end{abstract}

Keywords: Management of public participation, Developing Education Facilities and Infrastructure.

\section{Introduction}

One of the educational problems faced by the Indonesian nation is the low quality of education at every level and unit of education, especially primary and secondary education, [1]-[3]. Various efforts have been made to improve the quality of national education, one of which is the procurement and improvement of educational facilities and infrastructure. However, various indicators of educational quality have not shown significant improvement. Therefore, need improvement efforts, one of which is to reorient the implementation of education, namely from the management of quality based on the central to the school-based quality improvement management [4], [5].

Therefore, with greater autonomy, schools have greater authority in developing school facilities and infrastructure, so that schools are more independent, with their independence, 
schools are more empowered in developing educational facilities and infrastructure that of course, more in accordance with the needs and potentials it has [5], [6]. With flexibility, schools will be more agile in managing and utilizing school resources optimally and with the participation of school and community members directly in the development of school facilities and infrastructure, their sense of belonging to schools can be improved.

Public participation in the planning process is no longer a limited series of local meetings, but involves a series of legally required procedures, as part of the planning process [7]. Public participation is also a process which assists in providing authorities with information to be able to make decisions [8], [9]. Involvement of the community in the implementation of education in schools is an important thing that must exist, because: first, if a decision is made by the people together, then the result of the decision will be better; second, the people involved in the decision-making will feel belonging and committed; thirdly, the people involved in decision making and implementation will be in the best position; fourth, if people are involved and responsible, the school will more effectively serve the needs of the students and the community; and fifth, if principals and teachers run their school management more openly, then the community will have a strong share in making decisions about school activities [8], [10].

Based on the results of research on community participation in schools shows the level of participation is still low. The results research conducted by [11] about the level of community involvement in education which shows that public participation in education is low because it has not reached the level of the emergence of a sense of community ownership of the school or commonly referred to as school ownership.

Public participation theory put forward [12] mentions that community participation includes three criteria that form (participation form), top-down (school efforts to involve the community in the program), bottom-up (participation by the community to be involved in the program).

Community participation enabled the intervention area resources [7], [13]. This community participation theory can be used to observe community participation in development or educational programs, as the following [12] states "participation typology is used to systematically examine community participation in development projects and education projects". For more details, the theory of community participation can be seen in Table 1 below.

Table 1. Framework for Community Participation

\begin{tabular}{llll}
\hline Form & Top-Down & Bottom-UP & Function \\
\hline Nominal & Legitimation & Inclusion & Display \\
Instrumental & Efficiency & Cost & Means \\
Representative & Sustainibility & Leverage & Voice \\
Transformative & Empowerment & Empowered & Means/end \\
\hline
\end{tabular}

Other research results concerning community participation in schools conducted by [10] which states that that the participation of the community in primary and secondary education is low seen from three aspects of participation pattern, namely relationship pattern, organizational pattern and cooperation pattern.

Researchers take MTs NIPI Rakha because it is a private educational institution that stands out and is able to compete with other schools, both public and private, especially in the development of facilities and infrastructure. The focus of this research is, how is the model of 
community participation in the development of educational facilities and infrastructure in MTs NIPI Rakha Amuntai. In accordance with the focus of the research above, this study aims to find a model of community participation in the development of educational facilities and infrastructure in MTs NIPI Rakha Amuntai.

\section{Method}

This research uses a qualitative approach, type of case study. Key informants in this study were Chairman of the foundation, Head of the madrasah, Wakamad facilities and infrastructure, school committee MTs NIPI Rakha Amuntai South Kalimantan and surrounding communities. The data were collected using in-depth interview, participant observation, and documentation study. Data analysis includes single site data analysis with data analysis techniques: data reduction, data presentation and conclusion [14]-[16]. Checking the validity of data is done through credibility, transferability, dependability, and confirmability.

\section{Result and discussion}

\subsection{Result}

Head of Madrasah MTs NIPI Rakha in the development of these facilities and infrastructure perform activities; planning and budgeting, procurement, maintenance, and evaluation. This is as the result of an interview with the head of MTs NIPI Rakha below.

The development of facilities and infrastructure in this madrasah starts from planning and budgeting, procurement, maintenance, and supervision or evaluation. Activity activities cannot be separated from the participation of the community, both parents santriwati, alumni madrasah, community leaders, local communities and so forth.

Planning and budgeting, the head of the madrasah perform needs analysis based on the fact of existing learning facilities and infrastructure, then discussed it with teachers, education personnel, Rakha Foundation officials and components of the community involved in educational training in MTs NIPI Rakha, such as santriwati's parents/ guardians, Rakha alumni, and some community leaders.

Procurement of facilities and infrastructure in MTs NIPI Rakha is using the cost of government such as cooperatives from the Minister of UKM, laboratory buildings, digital libraries and Place of Business Development Santriwati from Pekapontren Department of Religion. Financing from parents/guardian santriwati, alumni and the general public such as procurement of office equipment, classroom equipment, and others.

Utilization of these facilities and infrastructure is concerned the head of the madrasah to be useful for improving the quality of learning, in addition, the head of the madrasah is concerned with the efficiency of costs and benefits, this is related to the priority scale in the allocation of education funds, for example the procurement of textbooks takes precedence over the physical environment of madrasah.

The evaluation aims to obtain accurate information that will be used for planning and budgeting the next period, as well as information that will be submitted to all components involved in the implementation of education on MTs NIPI Rakha. Community participation 
has an important role in improving the quality of MTs NIPI Rakha. The scope of the target of the implementation of community participation on MTs NIPI Rakha there are three groups, namely:

\subsubsection{Group of Parents/Guardians of Santriwati}

Behind the achievements of MTs NIPI Rakha good always found involvement and linkage of parents/guardian santriwati, and the reverse behind the failure of education programs is often caused by the potential of parents and guardians of santri and santriwati who are not managed effectively. In order for the potential of wali santriwati can be utilized by MTs NIPI Rakha optimally, formed Committee/Majelis Madrasah consisting of parents/guardian santriwati and public figure. As with the results of interviews with one of the parents santriwati as well as part of the committee MTs NIPI Rakha following.

This madrasah committee is a place for us to channel our aspirations and is a form of participation in the organization of our children's education and with this ksomite we can also know the development of our children and the needs of madrasah to achieve quality education in MTs NIPI Rakha.

The Madrasah MTs NIPI Rakha Madrasah Committee and the parents/guardian of santriwati are able to discuss the needs of the madrasah needs related to their children's education through deliberation. Most discussed in the deliberation is the need for educational facilities and infrastructure so that in the meeting parents/guardian santriwati can convey suggestions and criticism in the fulfillment. In addition, parents/guardian santriwati can assist in the development of educational facilities and infrastructure in MTs NIPI Rakha.

The madrasah committee has a direct interest in the progress of MTs NIPI Rakha, because with this committee, it is easier to approach madrasah with santriwati guardian who can realize the guardian of santriwati about the importance of their participation in education especially in the development of facilities and infrastructure that support the learning process in MTs NIPI Rakha for the benefit of their children in the future.

\subsubsection{Alumni group of Santri/IKA Rakha (Family Association of Alumni Rasyidiyah Khalidiyah)}

Alumnus Rakha scattered in various cities and regions, directly or indirectly they do socialization to the community about education programs in Rakha. Therefore, Rakha Alumni Family Association is one of the means that connects Rakha pesantren with the wider community.

In addition, Rakha alumni who have been successful in the religious, political, trade and so on spreading not only in North Hulu Sungai Regency but have spread to other regions and even other provinces, this is a very valuable asset for Rakha boarding school, because of the high emotional ties with the alma mater, most of them become donors who help to develop madrasah especially in educational facilities and infrastructure. This is as with the results of interviews with the secretary of the foundation of Rakha boarding school following.

The Rakha alumni here are many who have become religious leaders (ulama), public figures, political figures and so on who spread not only in Hulu Sungai Utara District but have spread to other regions even other provinces. These alumni are the ones who donate money for the development of facilities and infrastructure at Rakha pesantren. 
Based on the results of the interview, Rakha alumni have a very important role to the development of educational facilities and infrastructure, especially in the physical development of madrasah, either in the form of building/local madrasah, teaching media, madrasa land and so on by becoming a permanent donor at boarding school Rakha.

\subsubsection{Community groups broad/general}

The relationship between MTs NIPI Rakha and the community through various activities, such as the exhibition which is often held in Amuntai Heroes Square in order to commemorate the national holidays and the anniversary of North Hulu Sungai Regency, and bazaars for the muassis and alumni reunions, held in the Rakha complex open to the general public. The aim is to demonstrate the progress that Rakha Pesantren has made to the community so that it can create a positive impression of the people on Rakha.

Relations with the community is also in the field of business, for example about the development of santri business in making peci. In addition, in the field of health is also established with the Puskestren which not only serve the health of students but also for the community around Rakha.

Promotion of good relations or cooperation with the general public can contribute to a madrasah, especially in the maintenance and supervision of madrasah facilities. The surrounding community who cares about madrasahs participate in maintaining and maintaining madrasah facilities and infrastructure. In addition, the community can also convey the aspirations, suggestions, and criticisms to madrasas for the development and progress of madrasah. Such conditions are like the following santriwati's statements.

I can also convey my aspirations, suggestions, and criticisms to the madrasah if something is distracting around me for madrasah progress.

Based on the statement of the parents, the community participation in MTs NIPI Rakha was implemented in three groups, namely the parents/guardian santriwati, IKA Rakha and the general public. Such community participation in addition to providing suggestions and criticism, mostly related to assisting in the form of materials or money that will be used madrasah to complement the needs and development of facilities and infrastructure madrasah. As with the results of interviews secretary foundation boarding school Rakha following.

Participation gave by the community especially Rakha alumni who have been successful in the form of material aid or money to complete the needs and development of madrasah facilities and infrastructure.

Based on the above interviews, every assistance given to Rakha boarding school, either from parents/guardian santriwati, alumni, government officials, and the general public, then the management will be arranged by the foundation in cooperation with the units under the auspices of Rakha Foundation. After analyzing the per unit needs then the aid is left to the unit in need by forming a working team. The work team will plan and implement it by being supervised and accounted to the boarding school of Rakha boarding school. This is what happened in the development of facilities and infrastructure in MTs NIPI Rakha.

Although the facilities and infrastructure in MTs NIPI Rakha still have shortcomings the existing facilities and infrastructure are better than the surrounding madrasah so that the 
madrasah has more value, not only in the academic field but also in terms of educational facilities and infrastructure.

\subsection{Discussion}

Based on the research results, the participation rate in MTs NIPI Rakha is quite high, that is at level 3. One of the community support in the development of facilities and infrastructure is the commitment of groups that have been formed madrasah, namely: 1) group of parents/guardian santriwati, from this group, then formed Committee/Majelis Madrasah; 2) the Alumni group of Santri/IKA Rakha (Family Association of Alumni Rasyidiyah Khalidiyah); and 3) broad community groups to assist the fulfillment of education facilities and infrastructure, but more prominent is the involvement of IKA Rakha in the provision of funds for the fulfillment of facilities and infrastructure that support the achievement of learning.

In addition to funding, another form of community participation is the involvement of donors who are members of IKA Rakha in planning and budgeting, by participating in discussions with teachers, education personnel, Rakha Foundation officials and the components involved in educational training at MTs NIPI Rakha after the head of the madrasah conducted a needs analysis based on the actual learning facilities and infrastructure. As for the implementation and supervision did by madrasah without involving the community. More details of the results of the analysis of the level of community participation can be seen in Table 2 below.

Table 2. Results Operationalization of Community Participation Factors in MTs NIPI Rakha Amuntai

\begin{tabular}{|c|c|c|c|c|c|}
\hline \multirow[b]{2}{*}{ No } & \multirow[b]{2}{*}{ Factors Observed } & \multicolumn{3}{|c|}{$\begin{array}{c}\text { Research Results Size of } \\
\text { Community Participation } \\
\text { Level }\end{array}$} & \multirow[b]{2}{*}{ Information } \\
\hline & & Form & $\begin{array}{l}\text { Participat } \\
\text { ion by } \\
\text { School }\end{array}$ & $\begin{array}{l}\text { Participat } \\
\text { ion } \\
\text { Accordin } \\
\text { g to } \\
\text { Society } \\
\end{array}$ & \\
\hline 1. & $\begin{array}{l}\text { The involvement of } \\
\text { community elements in } \\
\text { the planning of } \\
\text { educational facilities and } \\
\text { infrastructure } \\
\text { development }\end{array}$ & level 3 & level 3 & level 3 & $\begin{array}{l}\text { Participation is at level } \\
\text { 3. Donors who are } \\
\text { members of IKA } \\
\text { Rakha as community } \\
\text { representatives are } \\
\text { actively involved in the }\end{array}$ \\
\hline 1.1 & $\begin{array}{l}\text { Indicator: } \\
\text { The involvement of } \\
\text { community elements in } \\
\text { meetings with the agenda } \\
\text { of socialization and the }\end{array}$ & level 3 & level 3 & level 3 & $\begin{array}{l}\text { development planning } \\
\text { of sarpras and are } \\
\text { responsible for the } \\
\text { provision of funds. }\end{array}$ \\
\hline & $\begin{array}{l}\text { establishment of } \\
\text { committees for the } \\
\text { construction of facilities } \\
\text { and infrastructure } \\
\text { - Attendance of }\end{array}$ & & & & $\begin{array}{l}\text { Participation tends to } \\
\text { exist at level 2, since } \\
\text { the form of } \\
\text { participation tends to } \\
\text { be in the form of funds. }\end{array}$ \\
\hline
\end{tabular}


community elements in

meetings

- The contribution of community elements in the form of donations of funds, energy, thoughts in the meeting community elements in the implementation of education facilities and infrastructure development

3. The involvement of the community element in supervising the development of educational facilities and infrastructures

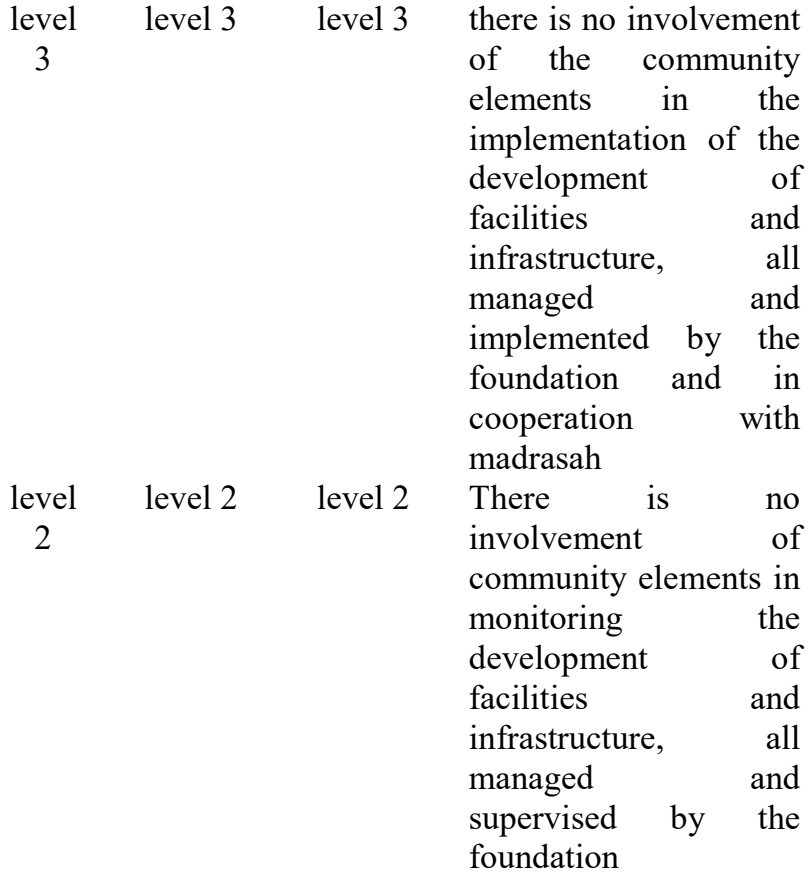

Based on Table 2, factors observed in analyzing the level of community participation include the factors of planning, implementation, and supervision of educational facilities and infrastructure development. First, the factors of planning the development of facilities and infrastructure, including the involvement of community elements in socialization meetings and the formation of work teams.

Furthermore, the implementation factor, including the involvement of community elements in the implementation of development and involvement of community elements in financial documentation. The third factor, the involvement of community element in the supervision of education facilities and infrastructure.

Factors planning of education facilities and infrastructure, the form of participation that arises is the involvement of donors who are members of IKA Rakha as representatives of society to participate with schools socialize the development of facilities and infrastructure to the school community and plan funding for the implementation of the development. This form of participation exists at level 3, namely the representation of elements of society in planning the development of facilities and infrastructure. This characteristic is called a representative. 
Furthermore the criteria of participation by the school, emerging community participation also exist at level 3. The school side encourages the involvement of the community in planning the development of education facilities and infrastructure. This characteristic is called sustainability; the madrasah considers important and encourages the involvement of the community in planning the development of educational facilities and infrastructures.

Participation criteria according to the community are at level 3 . Namely the community considers their participation is important in planning the development of facilities and infrastructure. This is referred to as leverage, are the elements of the community involved assume that it is important to be involved in planning the development of educational facilities and infrastructure.

The involvement is seen in the meeting of the formation of the development of facilities and infrastructure. In the meeting the donors who donated money for the development to know how the planning and implementation of infrastructure development later.

Support from the community is evident from the community's commitment to preparing to fund for the development of these facilities and infrastructure, but in terms of providing suggestions, support, thought, the passive tend to be the second level picture in the planning program or called instrumental, the lack of representation of the elements of society in giving suggestions and thoughts.

Such community involvement is a madrasah effort to encourage community elements to engage in meetings, socialization and funding planning. These efforts are included in the efficiency characteristics of the school or participation at level 2. As for the point of view of the community, the important participation is to provide funds in the development of facilities and infrastructure. This characteristic is referred to as cost, or participation is at level 2.

The community is not involved in the implementation and supervision of the development of education facilities and infrastructure, because it is all implemented and managed by Rakha Foundation in cooperation with units under its auspices and all supervision is done by Rakha Foundation.

Based on the above analysis, it is known that the level of community participation that occurs in the planning stage tends to be at level 3 , the representative is the representation of elements of society in the development planning of facilities and infrastructure, in this case, represented by the donor elements incorporated in IKA Rakha. However, in the implementation and supervision of educational facilities and infrastructure development, there is no community participation. This is because in addition to the madrasah, the opportunity for the community to participate, also the community perceives unimportant involvement of the community in the implementation and supervision because more know about madrasah is the madrasah itself.

Based on the above description, local people are involved in the development of educational facilities and infrastructure by the needs (need for affiliation, need for power and need for achievement) so that the formal findings of this research is Participation Based Needs of Local Community. This is in line with [17] that community participation and sustainability involves local choice because people are the local experts, in line with the idea of an indigenous knowledge system. Research result which shows that community participation in SDN Jeruk III Kecamatan Bandar Kabupaten Pacitan is open management is a form of community involvement starting from the planning process, determining, running, supervising and conducting participatory evaluation [5]. It is also based on the results of [2] study which shows that parents and community groups should be involved in the development of education from the planning, implementation, utilization and evaluation process. 


\section{Conclusion}

Community participation in the development of facilities and infrastructure in MTs NIPI Rakha is in level 3, namely: form; representative (the representation of elements of society in the planning of development of facilities and infrastructure), top-down; sustainability (the involvement of the community in planning the development of educational facilities and infrastructure), bottom-up; leverage (the community considers their participation important in the planning of infrastructure development). So this research can be concluded that the model development of educational facilities and infrastructure in accordance with the needs (need for affiliation, need for power and need for achievement) so that the formal findings of this research is Participation Based Needs of Local Community.

\section{References}

[1] A. A. Yudhi, "Pengembangan Mutu Pendidikan Ditinjau Dari Segi Sarana," J. Cerdas Sifa, vol. 1, no. 1, 2012.

[2] S. Hermanto, "Peran Serta Masyarakat Dalam Pendidikan," Manajemen Berbasis Sekolah, 2014.

[3] Efa, "The Effect Of Work Culture Pedagogic Competence And Work Commitment Toward Task Performance Teacher Vocational High School Bandar Lampung,” J. Ilm. Educ. Manag., vol. 7, no. 1, 2016.

[4] Mustaqim, "Partisipasi Masyarakat Dalam Meningkatkan Mutu Pendidikan," AlMabsut J. Stud. Islam dan Sos., vol. 10, no. 1, 2016.

[5] B. Wiratno, "Partisipasi Masyarakat Dalam Pendidikan," J. Pendidik. Ilmu Sos., vol. 26, no. 1, 2016.

[6] W. A. Mahardika, "Studi Keadaan Sarana Dan Prasarana Penunjang Aktifitas Pendidikan Jasmani Olahraga Dan Kesehatan Sekolah Dasar Negeri Se-Kecamatan Jatinom Kabupaten Klaten Tahun 2009,” Surakarta, 2009.

[7] R. Heffron and P. Haynes, "Challenges to the Aarhus Convention: Public Participation in the Energy Planning Process in the United Kingdom," J. Contemp. Eur. Res., vol. 10, no. 2, 2014.

[8] P. F. A. Matshe and J. P. Victor, "Promotion of Public Participation in School Environment," Mediterr. J. Soc. Sci., vol. 4, no. 13, 2013.

[9] M. A. Castillo, "Public Participation, Mayoral Control, and the New York City Public School System," J. Public Delib., vol. 9, no. 2, 2013.

[10] P. Buddu, "Partisipasi Masyarakat dalam Pendidikan Dasar dan Menengah," $J$. Pendidik. dan Kebud., vol. 15, no. 3, 2009.

[11] S. Faisal, Partisipasi Masyarakat Terhadap Sekolah. Jakarta: Depdiknas. UNM, 2007.

[12] M. D. Ternieden, "A Case Study for Community Participation in Primary Education in Three Rural Village School in Ethiopia," The George Washington University, 2009.

[13] M. P. Armado, C. V Santos, E. B. Moura, and V. G. Silva, "Public Participation in Sustainable Urban Planning," Int. J. Hum. Soc. Sci., vol. 5, no. 2, 2010.

[14] Milles and Huberman, Analisis Data Kualitatif. Jakarta: UI-Press, 1992.

[15] J. W. Creswell, Research Design. Pendekatan Kualitatif dan Kuantitatif. Jakarta: KIK Press, 2002.

[16] B. Bungin, Penelitian Kualitatif. Jakarta: Prenada Media Group, 2007.

[17] E. D. Laah, J. O. Adefila, and R. O. Yusuf, "Community Participation in Sustainable 
Rural Infrastructural Development in Riyom Area, Plateau State of Nigeria," J. Econ. Sustain. Dev., vol. 4, p. 19, 2013. 